\title{
DEVOPING THE READING SKILLS BY THE AID OF CHOSEN STRATEGIES
}

\section{[ROZVIJANIE CITATELSKYCH ZRUCNOSTI POMOCOU VYBRANYCH STRATEGII]}

\section{Dominika Hosova}

doi: 10.18355/PG.2019.8.1.12

\begin{abstract}
Reading skills are one of the most important factors that influence a pupil's learning process. It is for this reason that their development within the competence of the teacher is a significant part of education. In the theoretical analysis, we specify the reading literacy and its reflection in education. The paper also focuses on specific strategies by which the development of reading literacy is applicable and applicable to each subject.
\end{abstract}

\section{Key words}

strategies, literacy, analysis, education process

\section{Anotácia}

Čitatel'ské zručnosti sú jedným z najdôležitejších faktorov, ktoré ovplyvňujú vzdelávací proces žiaka. Práve z tohto dôvodu je ich rozvíjanie v kompetencii učitel'a nezanedbatel'nou súčastou vzdelávania. V rámci teoretickej analýzy bližšie špecifikujeme čitatel'skú gramotnost' a jej odraz v edukácii. Príspevok sa orientuje aj na konkrétne stratégie, pomocou ktorých je rozvíjanie čitatel'skej gramotnosti využitel'né a aplikovatel'né na každý vyučovací predmet.

\section{Kl'účové slová}

stratégie, gramotnost', analýza, vzdelávací proces

Úvod

„Ak nemá čítanie vplyv na náš život, konanie a myslenie, vtedy je škoda čitat." “ Anton Pavlovič Čechov

Čitatel'ské zručnosti nie sú podstatou iba pre školské vzdelávanie, ale aj pre rozvoj celoživotného vzdelávania. V súčasnej dobe sa stavia na čitatel'skú gramotnost' vel'ký dôraz hlavne z dôvodu, že čítanie nie je iba inštrumentom na dosiahnutie ciel'ov, zdôrazňuje aj aktívnu a iniciatívna úlohu čitatel'a pri porozumení a využívaní informácií nie iba v školskom prostredí. Samotné porozumenie textu je schopnost', ktorú je potrebné rozvíjat'. Mieru porozumenia čítaného textu ovplyvňujú ciel’avedomé stratégie práce s textom, ktoré poznáme pod pojmom metakognitívne procesy. Vd’aka týmto procesom čitatel' vedome riadi vlastný proces čítania, reguluje ho a kontroluje. Aj $\mathrm{z}$ tohto dôvodu je nevyhnutné, aby si žiaci osvojili prostriedky a stratégie, ktoré žiakom ul'ahčujú prácu s textom. 


\section{Čitatel'ská gramotnost'}

Pod pojmom čitatel'ská gramotnost' všeobecne označujeme schopnost' porozumiet' písaným textom. Miera porozumenia textu označuje úroveň čitatel'skej gramotnosti. Medzi širšie vymedzenie čitatel'skej gramotnosti podl'a L. Kunovej a V. Burjana (2011) patrí okrem porozumenia textu aj vzt’ah k čítaniu, aplikovanie prečítaných informácií a poznatkov v rámci sebarozvoja a bežného života, schopnost' vyslovit' vlastný názor a dojmy z prečítaného textu, komunikovat' o ňom s inými l'ud'mi ale aj metakogníciu schopnost' sledovat' vlastné procesy porozumenia textu. Pojem čitatel'ská gramotnost' výstižne vyjadruje R. Pierrová (1992) ako vzt’ah, ktorý človek nadviaže s písaným slovom.

Štúdie gramotnosti PISA a PIRLS nazerajú na čítanie a písanie ako na súbor vedomostí a zručností, ktoré je jednotlivec schopný uplatnit' pri práci s rozličnými textami. PIRLS charakterizuje čitatel'skú gramotnost' ako „schopnost' rozumiet' formám písaného jazyka, ktoré vyžaduje spoločnost' a/alebo jednotlivci, a tieto formy použivat'. Mladí čitatelia môžu odvodzovat význam zo širokej škály textov. Č́tajú, aby sa učili, aby sa zapojili do spoločenstva čitatelov, a čitajú tiež pre zábavu“ (Mullis, I. V. S., a kol., 2009, s. 11).

Za to PISA presahuje definíciu iba dešifrovaním či porozumením textu a obsahuje tiež pochopenie a následné použitie nadobudnutých informácií. Môžeme ju teda definovat' ako ,schopnost' porozumiet' pisanému textu, premýšlat' o ňom a použivat' ho na dosiahnutie vlastných ciel'ov, na rozvíjanie vlastných vedomostí a potenciálu a na aktívnu účast' v spoločnosti“"(OECD, 2003, s. 108).

Predchádzajúca definícia zohl'adňuje také zložky čitatel'skej gramotnosti, ktoré je možné testovat' a merat'. Rozlišujú sa tri aspekty čitatel'skej gramotnosti:

- získavanie informácií,

- vytváranie interpretácie,

- posúdenie textu.

V definícii čitatel'skej gramotnosti štúdie PISA 2009 môžeme badat' prvok zaangažovanosti čitatel’a do čítania (Koršňáková, P., a kol., 2010).

V školskej praxi môžeme zjednodušene vysvetlit' čitatel'ské kompetencie ako schopnost' plynule čítat' a pritom vnímat' a rozumiet' ćítanému textu. Nie však vždy žiak čítaním porozumie textu. Dôležitá je aj rýchlost' čítania, schopnost' reprodukovat' text, pochopenie podstaty textu, logicky spájat' súvislosti, vyvodit' hlavné myšlienky, využitie obsahu textu na rôzne účely, vediet' si uchovat' vedomosti a správne využívat' slovnú zásobu, konštruovat' myšlienky nad rámec textu a ich spájanie s predošlými vedomost’ami a ich praktické uplatňovanie v bežnom živote. V tejto súvislosti uvádza K. Šebesta (1999) rýchlost' čítania ako jeden zo zásadných faktorov, ktorý značne vplýva 
na školskú úspešnost' žiakov. Ak nie je žiak schopný prečítat' text dostatočne rýchlo, svoju pozornost' obracia inam. Ďalšie zásadné faktory uvádza aktivitu a pozornost' pri čítaní.

Taktiež schopnost' čítat' a učit' sa prostredníctvom čítania je základnou akademickou zručnost’ou, ktorá je dôležitá pre školskú úspešnost' na všetkých úrovniach vzdelávania. Nízka čitatel'ská gramotnost' môže znižovat' efektívnost' učenia sa hlavne $\mathrm{z}$ dôvodu neporozumenia kl'účovým pojmom (Tomengová, 2010).

\section{Odraz čitatel'skej gramotnosti v edukácií}

Často sa v našom vzdelávaní stretávame $\mathrm{s}$ pojmami ako memorovanie a pasívne prijímanie informácií. Súvisí to hlavne s tým, že žiaci sú zväčša hodnotení podl'a toho, čo sa naučili naspamät. Výslednú známku nedávajú učitelia za tvorivé myslenia a aktivitu na hodinách, ale na základe písomiek či ústnej odpovede. Ako tvrdí M. Kemeňová (2006), rozvoj tvorivosti a kritického myslenia zo škôl vytláča rozsah predpísaného povinného učiva, ktorého prebratie bohato prepíña čas učitel'ov i žiakov. Dôraz sa kladie na memorovanie poznatkov, a pritom je priam absurdné, aby sa $\mathrm{v}$ časoch informatického rozmachu škola sústred'ovala na kvantitu osvojených informácií namiesto toho, aby sa venovala rozvíjaniu schopnosti samostatne si relevantné informácie vyhl'adat' a vediet' ich efektívne použit'. Dokazujú to aj výsledky PISA, TIMSS a PIRLS, ktoré porovnávajú úroveň žiakov v krajinách OECD a poukazujú na to, že práve tieto zručnosti našim žiakom chýbajú. Pätnástroční žiaci majú dokonca problém porozumiet' prečítanému textu a odpovedat' na jednoduché otázky vzt'ahujúce sa $\mathrm{k}$ jeho obsahu. Práve preto je dôležité odbúravat' memorovanie $\mathrm{v}$ školách. Klást' dôraz na aktívne učenie na hodine, pričom hlavný aktér je žiak, nie učitel'.

Výsledky výskumov PISA u slovenských žiakoch v čitatel'skej gramotnosti boli v roku 2015 štatisticky význame nižšie ako v roku 2009. A na základe týchto výsledkov sa pre Ministerstvo školstva, vedy, výskumu a športu SR oblast' čitatel'skej gramotnosti stala jednou z priorít pre vzdelávaciu politiku. Od toho sa predkladajú návrhy, odporúčania, ciele a stratégie na zlepšenie nie len v čitatel'skej gramotnosti (vid'. „Návrh odporúčaní na zlepšenie výsledkov žiakov v medzinárodnom meraní žiakov OECD - štúdii PISA“, „Národná stratégia zvyšsvania úrovne a kontinuálneho rozvíjania čitatel’skej gramotnosti“, „Opatrenia na zlepšenie úrovne čitatel'skej gramotnosti v Slovenskej republike“, školský rok 2016/2017 vyhlásený za Rok čitatel'skej gramotnosti).

K dopracovaniu ciel'ov napomôže podpora spolupráce medzi žiakmi, prepájanie poznatkov $\mathrm{z}$ ostatných vzdelávacích predmetov, inovácia pedagogických dokumentov, učebnice, metodické materiály, aktivity na podporu čítania žiakov, aktívne využívanie školských knižníc ako aj podpora celoživotného vzdelávania v oblasti rozvoja čitatel'skej gramotnosti. 
V oblasti vzdelávania učitel'ov Metodicko-pedagogické centrum (MPC) v Bratislave pripravilo súbor akreditovaných vzdelávacích programov pre učitel'ov zameraných na rozvoj čítania s porozumením určených pre učitel'ov bez obmedzenia vyučovacieho predmetu.

Podl'a Medzinárodného združenia pre čítanie (International Reading Association - IRA, 2007), kvalitní učitelia disponujú hlbokými znalost’ami, jasnými stratégiami, vel’a číajú, dokážu žiakov motivovat' k čítaniu.

Americký Národný panel pre čítanie (National Reading Panel) tvrdí, že naučit' žiakov všetky úrovne stratégie porozumenia písanému textu predstavuje náročnú úlohu. Učitel' si nevystačí len so zvládnutím obsahu textu, musí tiež vel'mi dobre poznat' samotné stratégie a ovládat', ktoré z nich najlepšie fungujú u jednotlivých žiakov a rozličných tém textov, a vediet' aj to, ako najlepšie vyučovat' využitie stratégie (NICHD, 2000).

V rizikovej skupine sa na základe PISA 2015 nachádzalo 32,1\% slovenských žiakov. Riziková skupina predstavuje žiakov, ktorí nedisponujú ani najzákladnejšími čitatel'skými zručnostami, ktoré sú nevyhnutné pre vzdelávanie. Štúdia PISA týchto žiakov považuje za rizikovú z dôvodu budúcej zát'aže pre spoločnost', pretože budú vyžadovat' zvýšené náklady na sociálnu ako aj zdravotnú starostlivost'. V konečnom dôsledku táto skupina žiakov má vážne problémy pri štúdiu, ako aj pri uplatňovaní na trhu práce. V tejto súvislosti sa začína povrávat' o novom fenoméne - bibliofóbii alebo a-gramotnosti, čo predstavuje trvalú l'ahostajnost' voči knihám a čítaniu.

Neuspokojivé výsledky nastolili otázky o analyzovaní príčin neúspechu slovenských žiakov i zámery zlepšit' úroveň čitatel'skej gramotnosti. Jedným z klúčových problémov školskej výučby je rozvíjanie schopnosti porozumiet' textu použitím metód a aktivít podporujúcich čítanie s porozumením, ktoré zahŕňajú aj efektívne spôsoby spracovania informácií z textu a riadenie procesov aktívneho čítania a učenia sa žiaka aplikáciou tzv. metakognitívnych stratégií. Zvyšovanie úrovne čitatel'skej gramotnosti zasahuje všetky vekové kategórie, všetky oblasti a taktiež všetky prostredia škola, rodina, práca. Preto je nevyhnutná podpora formálneho ako aj neformálneho vzdelávania.

V západných krajinách využívajú na zlepšovanie čitatel’skej gramotnosti na základných a stredných školách program nazývaný CORI (Concept-Oriented Reading Instruction). Autormi sú J. T. Guthrie a L. Bennett (1996), učitelia na základnej škole. Práve ich dlhoročné skúsenosti v piatej triede, kde žiaci mávali problémy s čítaním a nízku motiváciu k čítaniu sa rozhodli vybudovat' vyučovacie praktiky. Tento program je určený na rozvíjanie čítania s porozumením a tiež motiváciu k čítaniu. Učitelia, ktorí pracujú na základe tohto programu do vyučovania zarad’ujú týchto 5 praktík: 1 . poskytovanie tematických obsahových ciel'ov, 2. optimalizácia výberu, 3. praktické aktivity súvisiace sčítaním, 4. poskytovanie zaujímavých textov, 5. podpora 
spolupráce. Učitelia taktiež využívajú 6 stratégií čítania. Tento program je založený na modeli čitatel'skej angažovanosti (Model of Reading Engagement) od autorov Guthrie a Wigfielda (2000).

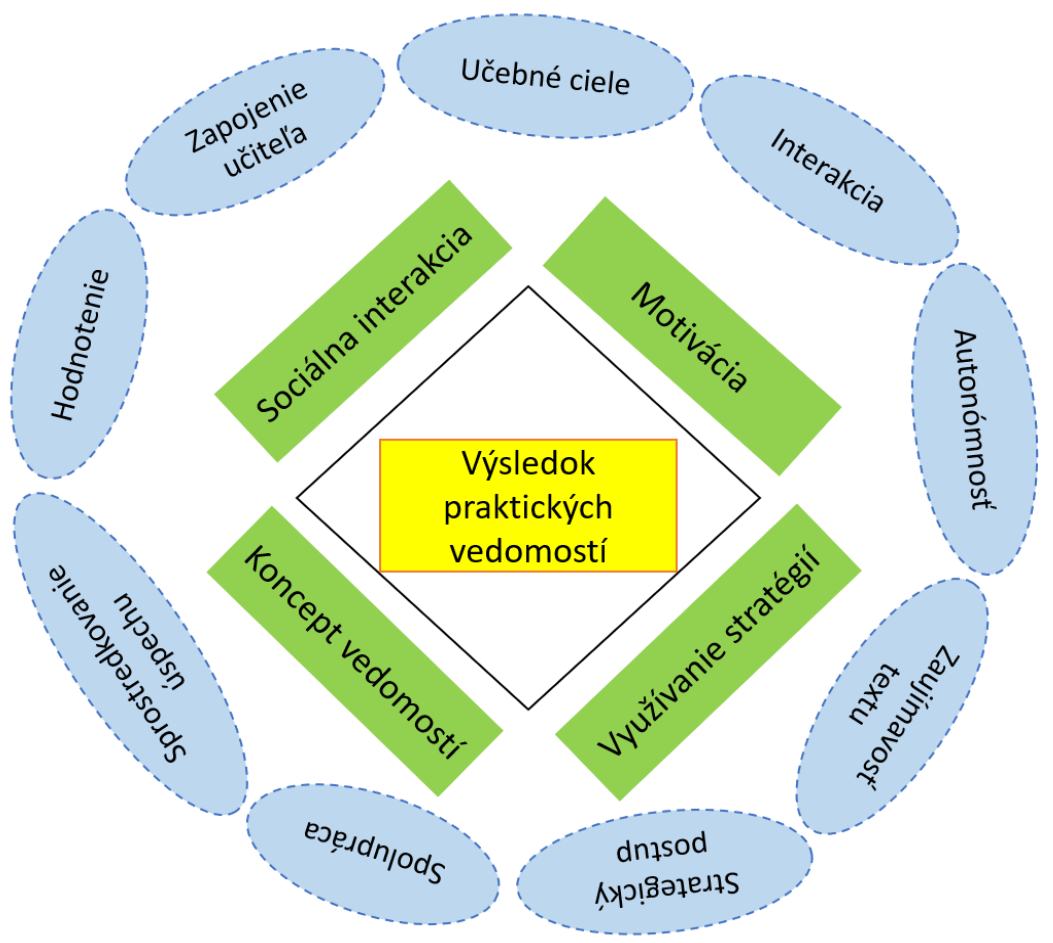

Obrázok 1. Model čitatel'skej angažovanosti (Guthie, J. T., Bennett, L., 2000)

\section{Stratégie na rozvoj čitatel'skej gramotnosti}

Stratégie pomáhajú žiakom skvalitňovat' a urýchl’ovat' učenie, stávajú sa prostriedkom efektívneho učenia sa. $\mathrm{V}$ súčasnosti je rozpracovaných viacero stratégií, prostredníctvom ktorých je možné rozvíjat' čitatel'skú gramotnost' (napr. Turek, I., 2003; Fisher, R., 2004; Gavora, P., 2008; Tomengová, A., 2010). Účinné stratégie rozvíjania čitatel'skej gramotnosti u žiakov, ktoré možno považovat' za uplatnitel'né naprieč všetkými vyučovacími predmetmi odporúča A Tomengová (2010). Ide o nasledovné:

- stratégia SQ3R, stratégia SQ4R (čitatel'ské strategické algoritmy),

- stratégia PLAN, stratégia PROR (heuristické strategické čítanie),

- stratégia KWL, produktívne učenie sa, strategické čítanie spojené s produkovaním otázok a odpovedí, kreatívne mapovanie obsahu textu (aktívne učenie sa),

- kritické čítanie verzus kritické myslenie. 
Pozitívny dopad na čitatel'skú gramotnost' žiakov má vedenie žiakov $\mathrm{k}$ osvojeniu si a následnému uplatňovaniu metakognitívnych procesov pri práci s textom. Podl'a P. Gavoru a kol. (2008) prebiehajú metakognitívne procesy (niekedy nazývané aj stratégie) pred čítaním, pri čítaní aj po čítaní. Pred čítaním sa žiak pripraví na tému, porozmýšl'a čo o téme vie. Počas čítania sleduje porozumenie textu, sleduje súvislosti, robí si poznámky. Po čítaní rieši úlohy a otázky $\mathrm{k}$ textu, vyhodnocuje informácie $\mathrm{z}$ textu.

Metakognitívne osvojené zručnosti pomáhajú žiakom aktívne čítat', učit' sa aktívne, efektívne spracovávat' informácie z textu a lepšie mu porozumiet'. A práve schopnost' spracovat' informácie $z$ textu je podl'a N. Kašiarovej (2008) podstatou čitatel'skej gramotnosti.

L'. Liptáková a M. Klimovič (2014) vo svojej štúdií zameranej na exekutívne funkcie a porozumenie textu spomenuli aj dizajn programov, ktoré sú zamerané na osvojenie si kognitívnych a metakognitívnych stratégií. Čo sa týka paralelného rozvíjania kognitívnych a metakognitívnych stratégií môžeme spomenút' tzv. priame vysvetl'ovanie - direct explanation (Paris, Winograd, 1990) kde učitel' opíše stratégiu, povie jej pozitíva a negatíva, vysvetlí jej uplatňovanie, ukáže spôsob a taktiež môže učiaci zhodnotit', či bola stratégia efektívna.

Ďalší prístup, resp. stratégia je učenie sa s oporou/lešením - scaffolded instruction, alebo tiež v literatúre uvádzaná ako scaffolding (Bayerlová, 2017; Beláková, 2018, Purvis, Cross, Sunshine, 2013). Scaffolding môžeme považovat' za jednu zo základných metód rozvoja čitatel'ských stratégií. Táto konkrétna stratégia sa vo väčšej miere spolieha na schopnost' učiaceho identifikovat' ciel' učenia za pomoci externého prostredia prostredníctvom modelovania stratégie a spätnej väzby dospiet' k osvojenie vhodnej stratégie na riešenie úloh. Konkrétny príklad pre používanie tejto metódy zo strany učitel'a je, že zo začiatku ked' je úloha nová, žiakovi poskytuje vel'kú podporu. Pomáha mu, povzbudzuje, akonáhle si žiak osvojí novú zručnost' a začína ju s úspechom používat', učitel' zo svojej podpory začína pomaly uberat'. Scaffolding je v skratke všetko to, čo učitel' robí, aby žiakovi ul'ahčil učenie. Táto metóda sa skôr využíva na vyučovaní cudzích jazykov a má svoje techniky.

R. L. Allington (2002) robil pozorovania viac ako sto dní v triedach a taktiež stovky rozhovorov s učitel'mi a žiakmi aby získal jasný obraz o tom, ako vyzerá dobré základné učenie čitatel'skej gramotnosti. Autor hovorí o teórii šiestich T ( $\mathrm{z}$ angličtiny time, texts, teaching, talk, task, testing).

1. Time - čas: rozsiahle čítanie je rozhodujúce pre rozvoj zručnosti čítania. Preto je dôležité poskytnút' žiakom dostatok času na čítanie, aby si upevňovali túto zručnost' a učili sa stratégiám čítania.

2. Texts - texty: ak majú žiaci počas školského dňa čítat', potrebujú bohatú ponuku kníh, ktoré sú aktuálne. Je dôležité vybrat' žiakom tie správne texty, aj ked' sa to môže zdat' jednoduché, vybrat' správne 
texty môže byt' pre učitel'ov náročné, pretože existuje široká škála možností.

3. Teaching - učenie: súčast'ou dobrej výučby je plánovanie, výber kvalitnej literatúry a učenie stratégií. Učitelia by mali explicitne vysvetlit' kognitívne a metakognitívne stratégie, ktoré by dobrí čitatelia mali ovládat'. Medzi užitočné stratégie, ktoré by si žiak mal osvojit' vd'aka učitel'ovi môžeme zaradit' stratégie dekódovania, stratégie skladania a samoregulačné stratégie.

4. Talk - rozprávanie: využívanie diskusie ako formu vyučovania, poskytnút' čas na prerozprávanie obsahu textu s ktorým sme pracovali, kníh, ktoré žiaci prečítali.

5. Task - úloha: každá by mala byt’ zmysluplná a potrebná na rozvíjanie potrieb žiakov.

6. Testing - testovanie: nemalo by sa používat' len na hodnotenie žiakov, ale malo by byt' skôr nápomocné na usmernenie učitel'a v smere, kde žiak potrebuje pomoc a kde sa má zlepšovat'.

Čo sa týka samotného výberu konkrétnej stratégie, záleží od jednotlivca žiaka. Je na ňom, ktorá stratégia sa mu najviac osvedčí, ktorú bude robit' automaticky a ul'ahčí mu proces učenia. Učitel' by mal žiakom vysvetlit' a ukázat' čo najviac stratégií, mali by si ich vyskúšat', vediet' ich aplikovat' na každej vyučovacej hodine pri práci s textom. Uplatňovanie stratégií by žiakom malo pomôct' $\mathrm{v}$ učení, lepšom pochopení textu a v konečnom dôsledku aj pomôct' kriticky mysliet' a spracovávat' informácie.

Schopnosti porozumiet' textu $\mathrm{v}$ rôznych situáciách, vyvodzovat' z prečítaného závery, posudzovat' zámery autora je jednou zo základ života každého človeka a prosperity celej spoločnosti. Rozvinutie čitatel'skej gramotnosti každého jedného žiaka na potrebnú úroveň by malo byt' jedným zo základných ciel'ov vzdelávania. Učitel' by mal podporovat' každého jedného čitatel'a a učit' ho efektívnym stratégiám, ktoré sú vhodné a šité priamo pre konkrétneho jednotlivca, vychádzajúc z jeho osobnosti, učebnému tempa a učebného štýlu. Celoživotné učenie sa nezaobíde bez aktívneho čítania spojeného zo skutočným porozumením textu. Taktiež je dôležité žiakom základných škôl ukázat', že čítanie môže bavit', môže im priniest' silné emócie ale aj životné poučenie.

Príspevok je výstupom riešenia projektu APVV-15-0368 s názvom Prax v centre odborovej didaktiky, odborová didaktika v centre praktickej prípravy.

\section{Bibliographic references}

ALLINGTON, R. L. 2002. What I've learned about effective reading instruction from a decade of studying exemplary elementary classroom teachers. In Phi Delta Kappan, vol 83, no 10. pp 740-747.

BAYERLOVA, T. 2015. Scaffolding ve výuce clil na 1. stupni Ž̌. Plzeň: Západočeská univerzita v Plzni, Fakulta pedagogická. [Diplomová práce]. 
BELAKOVA M. 2018. Metóda CLIL vo vyučovaní materinského jazyka v základných školách (stratégia scaffolding). In Slovenčinári. Časopis spoločenstva učitel'ov a priatel'ov slovenčiny. pp. 4-10.

FISHER, R. 2004. Učíme děti myslet a učit se: praktický průvodce strategiemi vyučování. Praha: Portál. 172 s. ISBN 80-7178-966-6.

GAVORA, P. a kol. 2008. Ako rozvíjat' porozumenie textu u žiakov. Nitra: Enigma. 193 p. ISBN 978-80-89132-57-7.

GUTHRIE, J. T. - VAN METER, P. - McCANN, A. - WIGFIELD, A. BENNETT, L. - POUNDSTONE, C. - MITCHELL, A. 1996. Growth of literacy engagement: Changes in motivations and strategies during conceptoriented reading instruction. In Reading Research Quarterly, vol 31. pp 306325.

GUTHRIE, J. T. - WIGFIELD, A. 2000. Engagement and motivation in reading. In Handbook of reading research. New York, NY: Longman. pp. 403-422.

KAŠIAROVÁ, N. 2008. Rozvoj čitatel'skej gramotnosti sa začína plánovaním procesov učenia. In: Pedagogické rozhl'ady, roč. 17, č. 2. s. 2-7.

KEMEŇOVÁ, M. 2006. Čo sa v škole naučíš, v živote akoby si našiel? Available online: https://www.etrend.sk/ekonomika/co-sa-v-skole-naucis-vzivote-akoby-si-nasiel-diskusia.html

KORŠŇÁKOVÁ, P. a kol. 2010. Národná správa OECD PISA SK 2009 Bratislava : NÚCEM. Available online:

http://www.nucem.sk/documents//27/medzinarodne_merania/pisa/publikacie _a_diseminacia/1_narodne_spravy/N\%C3\%A1rodn\%C3\%A1_spr\%C3\%A1v a_PISA_2009.pdf.

KUNOVÁ, L. - BURJAN, V. 2011. Čitatel'ská gramotnost'. Tematická príloha časopisu Dobrá škola. In Dobrá škola. ISSN 1338-0338, 2011, vol. 3, n. 1, pp. 1-8.

LIPTÁKOVÁ, L., KLIMOVIČ, M. 2014. Exekutívne funkcie a porozumenie textu: čitatel'ské stratégie v kognitívnej stimulácii. In História, súčasnost' a perspektívy vzdelávania na Pedagogickej fakulte Prešovskej univerzity v Prešove. Prešov: Vydavatel'stvo Prešovskej univerzity. ISBN 978-80-5551237-2. pp. 754-764.

MULLIS, I.V.S. et al. 2009. PIRLS 2011 Assessment Framework. Lynch School of Education, Boston College: TIMSS \& PIRLS International Study Center.

Národná stratégia zvyšovania úrovne a kontinuálneho rozvíjania čitatel’skej gramotnosti.

Návrh odporúčaní na zlepšenie výsledkov žiakov v medzinárodnom meraní žiakov OECD - štúdii PISA.

OECD 2003. The PISA 2003 Assessment Framework - Mathematics, Reading, Science and Problem Solving Knowledge and Skills.

Opatrenia na zlepšenie úrovne čitatel'skej gramotnosti v Slovenskej republike ŠEBESTA, K. 1999. Od jazyka ke komunikaci. Praha: Karolinum. 157 p. ISBN 8071847119.

PARIS, S. G. - WINOGRAD, P.1990. How metacognition can promote academic learning and instruction. In: Dimensions of Thinking and Cognitive Instruction. Hillsdale, NJ: Erlbaum, pp. 15 - 51. 
PIERRE, R. 1992. Savoir lire aujourd'hui: de la définition à l'évaluation du savoir-lire. In: Evaluer le savoir-lire. Logiques: Montréal. pp. 275-315.

PURVIS, K. B. - CROSS, D. R. - SUNSHINE, W. L. 2013. Dítě v nové rodině. Praha: Grada Publishing, 252 p. ISBN 978-80-247-4535-0.

SHRIVER, E. K. 2000. NICHD (National Institute of Child Health and Human Development). Report of the National Reading Panel. Teaching children to read: An evidence-based assessment of the scientific research literature on reading and its implications for reading instruction. Reports of the subgroups. Washington, DC: U.S. Government Printing Office. 480 p.

TOMENGOVÁ, A. 2010. Čitatel'ské stratégie zlepšujúce schopnost' učit' sa. Bratislava: MPC v Bratislave. 40 p. ISBN 978-80-8052-353-4.

TUREK, I. 2003. Ako sa naučit' učit? Prešov: MPC. 122 p. ISBN 8080453004 .

\author{
Dominika Hošová \\ Department of pedagogy \\ Faculty of education, \\ Constantine the Philosopher University in Nitra \\ Drazovska 4, Nitra \\ Slovakia \\ dominika.hosova@ukf.sk
}

